\title{
STUDY OF ADVANCED NANOSCALE ZRN/CRN MULTILAYER COATINGS
}

\author{
DOlga Maksakova ${ }^{1 *}$, (D) Alexander Pogrebnjak ${ }^{1,2}$, Vyacheslav Beresnev $^{3 * *}$, \\ (D)Vyacheslav Stolbovoy ${ }^{4}$, (DSónia Simoẽs ${ }^{5}$, Dosym Yerbolatuly ${ }^{6}$ \\ ${ }^{1}$ Sumy State University, 2, Rymsky Korsakov Str., 40007 Sumy, Ukraine \\ ${ }^{2} D$. Serikbayev East Kazakhstan State Technical University \\ 69, Protozanova Str., 070004, Ust-Kamenogorsk, The Republic of Kazakhstan \\ ${ }^{3}$ V.N. Karazin Kharkiv National University, 4, Svobody Sq., 61022 Kharkiv, Ukraine \\ ${ }^{4}$ National Science Center Kharkov Institute of Physics and Technology, 1, Akademicheskaya Str., 61108 Kharkiv, Ukraine \\ ${ }^{5}$ University of Porto, R. Dr. Roberto Frias, 4200-465 Porto, Portugal \\ ${ }^{6}$ Sarsen Amanzholov East-Kazakhstan State University \\ 34, 30Gvardeiskoi divisii Str., 070020, Ust-Kamenogorsk, The Republic of Kazakhstan \\ *E-mail: maksakova.tereshenko@gmail.com,**E-mail:v.beresnev@karazin.ua \\ Received April 12, 2019; revised May 2, 2019; accepted May 31, 2019
}

The scientific interest in the investigation of nitride composites as protecting materials in tool and machining industries intensively increases. The good oxidation resistance of $\mathrm{CrN}$ single-layer films and high melting point, good chemical and thermal resistance of $\mathrm{ZrN}$ compound are motive factors for designing of multilayer composites composed of these metal nitrides. The suggested advantages of $\mathrm{ZrN} / \mathrm{CrN}$ multilayer coatings as structural materials are the high-temperature resistance, high density and extreme hardness compared to the metal-nitride systems. Experimental $\mathrm{ZrN} / \mathrm{CrN}$ multilayer coatings were deposited on AISI 321 steel substrates by using a cathodic arc evaporation device equipped with two high-purity metal $\mathrm{Cr}$ and $\mathrm{Zr}$ targets. Structural, chemical and morphological characteristics together with mechanical properties of multilayer composites were analyzed by X-ray diffraction, scanning electron microscopy, energy-dispersive X-ray spectroscopy and Vickers hardness tester. SEM analysis revealed an increase of roughness and concentration of the droplets on the surface of the coatings when negative bias potential decreased to $-70 \mathrm{~V}$. The results of data obtained from the X-ray analysis showed (200) and (111) plane for $\mathrm{ZrN}$ and $\mathrm{Cr}_{2} \mathrm{~N}$ phases as the most intense. The peak positions of $\mathrm{ZrN}$ were shifted towards lower diffraction angles comparing with bulk values and indicated a decrease of the interplanar distance and formation of compressive stresses. The calculated lattice strain values in the $\mathrm{ZrN}$ were higher than those of the $\mathrm{CrN}$, indicated a greater presence of dislocations and defects in the lattice of $\mathrm{ZrN}$. The averaged crystallite sizes in $\mathrm{ZrN}$ and $\mathrm{CrN}$ layers were 11-14 and 7-12 nm, respectively. The maximum value of the Vickers microhardness was found to be $6600 \mathrm{HV} 0.01$ that is 2.1 and 1.8 times greater than the corresponding values of binary $\mathrm{CrN}$ and $\mathrm{ZrN}$ coatings.

KEYWORDS: nitrides, cathodic arc deposition, microstructure, elemental composition, structural-phase state.

The extension of the operational life of industrial equipment, components of installations, cutting, drilling and other machining tools stays a relevant task of science and technology of materials engineering till present. Moreover, nowadays at the stage of an enhanced economy of resources and in going to energy-saving technologies, this issue becomes even more acute. While functioning, the product surface layers undergo the strongest loading, physical, chemical and thermal effects. One of the ways to protect and improve various material properties is to modify it due to deposition of nanostructured thin coatings on its surface.

Cathodic-arc technique is a multipurpose method of coating deposition since the resulted products gain wide industrial distribution because of their suitability for various functional purposes $[1,2]$. Transition metal nitride coatings with a thickness of a few microns are one of the most studied and widely used materials. Unfortunately, the possibilities of increasing the hardness and plasticity of the surface layer during the deposition of simple nitrides are practically depleted, since at mid-temperature range mononitrides initiated to be thermally unstable [3-5].

Recently, nanoscale coatings of a complex elemental and phase composition realized through the multilayer coating concept are of considerable interest, since combinations of various elements make it possible to use the best properties of two or several metals and their nitrides [6,7].

This paper describes the effect of deposition parameters on the structure, elemental and phase composition of multilayer coatings $\mathrm{ZrN} / \mathrm{CrN}$, as well as their mechanical characteristics.

\section{EXPERIMENTAL DETAILS}

The $\mathrm{ZrN} / \mathrm{CrN}$ multilayers were fabricated by the cathodic-arc method in a Bulat 6 deposition system [8], which composed of a vacuum chamber, vacuum pumping system, nitrogen supply system that worked at pressure between $10^{-5}$ to $10^{-2} \mathrm{~Pa}$, arc power supplies that produced the current from 50 to $200 \mathrm{~A}$, substrate power supply that ensured constant negative bias voltage and automatic rotation system for substrate holder. Within the working chamber, there was an electrode formed by an anode, where the steel substrates were placed, and cathodes with the $\mathrm{Zr}$ and $\mathrm{Cr}$ targets. Metal targets were in the opposite positions and the substrates were mounted on two sides of a rotating substrate holder between the two targets. Experimental coatings were deposited by alternately rotating the substrates between $\mathrm{Cr}$ and $\mathrm{Zr}$ targets. The arc current of $100 \mathrm{~A}$ was constantly applied for all samples. When the first multilayer ZrN/CrN film started to produce, the chamber was filled with nitrogen at a pressure of $0.03 \mathrm{~Pa}$. For other samples of the coatings, it changed 
as the goal of this investigation was to evaluate the influence of deposition conditions on morphology, phase state and mechanical properties of multilayer condensates. Specific details of the deposition process of the multilayer coatings were summarized in Table 1.

The surface and cross-section structure, as well as the chemical composition of the coatings, were analyzed by scanning electron microscopy with energy dispersive X-ray spectroscopy facilities (SEM-EDS) in a FEI Quanta 400 FEG ESEM/EDAX Genesis X4M. For the XRD characterization technique, we used a Panalytical X'Pert Pro MPD diffractometer. Phase identification was realized through the ICDD data. Mechanical properties were evaluated by Vickers microhardness tests in a Struers Duramin-5 using a load of $98 \mathrm{mN}$ (HV0.01).

Table 1.

Deposition conditions of multilayer $\mathrm{ZrN} / \mathrm{CrN}$ coatings.

\begin{tabular}{|c|c|c|c|c|c|c|c|c|}
\hline $\begin{array}{l}\text { Sample } \\
\text { number }\end{array}$ & $\begin{array}{c}\text { Arc } \\
\text { current } \\
I_{d}, \mathrm{~A} \\
\end{array}$ & $\begin{array}{c}\text { Bias } \\
\text { voltage } \\
U_{S}, \mathrm{~V} \\
\end{array}$ & $\begin{array}{c}\text { Substrate } \\
\text { temperature } \\
T_{S},{ }^{\circ} \mathrm{C} \\
\end{array}$ & $\begin{array}{c}\text { Nitrogen } \\
\text { pressure } \\
P_{N}, \mathrm{~Pa} \\
\end{array}$ & Exposing time $t, \mathrm{~s}$ & $\begin{array}{c}\text { Total } \\
\text { deposition } \\
\text { time, } \mathrm{h}\end{array}$ & $\begin{array}{l}\text { Deposition } \\
\text { rate } R_{d}, \mathrm{~nm} / \mathrm{s}\end{array}$ & $\begin{array}{l}\text { Number } \\
\text { of layers }\end{array}$ \\
\hline 1 & \multirow{4}{*}{100} & \multirow{2}{*}{-70} & \multirow{4}{*}{250} & 0.04 & \multirow{4}{*}{$\mathrm{ZrN}: 10 / \mathrm{CrN}: 10$} & \multirow{4}{*}{1} & 3.25 & \multirow{4}{*}{354} \\
\hline 2 & & & & 0.43 & & & 3.5 & \\
\hline 3 & & \multirow{2}{*}{-150} & & 0.16 & & & 4.5 & \\
\hline 4 & & & & 0.03 & & & 2.65 & \\
\hline
\end{tabular}

\section{RESULTS AND DISCUSSION}

Morphologic study

The morphology of the PVD-coatings is basically controlled by the process characteristics, i.e. substrate temperature $\left(T_{S}\right)$, working gas pressure $\left(P_{N}\right)$, the negative bias voltage applied to the substrate $\left(U_{S}\right)$ and an arc current $\left(I_{d}\right)[9,10]$. During the surface analysis of experimental coatings, it is revealed that micro-relief of the surface is expressed by numerous shallow different-sized depressions due to the growth of crystallites of different sizes. The formation of the droplets with a particle diameter averaged from 2 to 5 microns is observed for all the coatings. Increasing the nitrogen pressure up to $0.43 \mathrm{~Pa}$ while the deposition does not introduce any special changes in the surface morphology. However, increasing the energy of the precipitated flow through the bias potential to $-200 \mathrm{~V}$ significantly reduces the concentration of the droplets on the surface. Probably, with the increase of the substrate bias value, the energetic particles bombardment becomes more intensive and activates the process of cleaning the surface from smaller fractions. Fig. 1a shows the cross-sectional SEM image of the multilayer sample number 4 . The heterophase interfaces between $\mathrm{ZrN}$ and $\mathrm{CrN}$ layers are rather straight and immiscible. The dark contrast layers correspond to the $\mathrm{CrN}$, while lighter ones indicate the binary $\mathrm{ZrN}$. The structure of layers is dense, no boundary porosity or other defects exist.

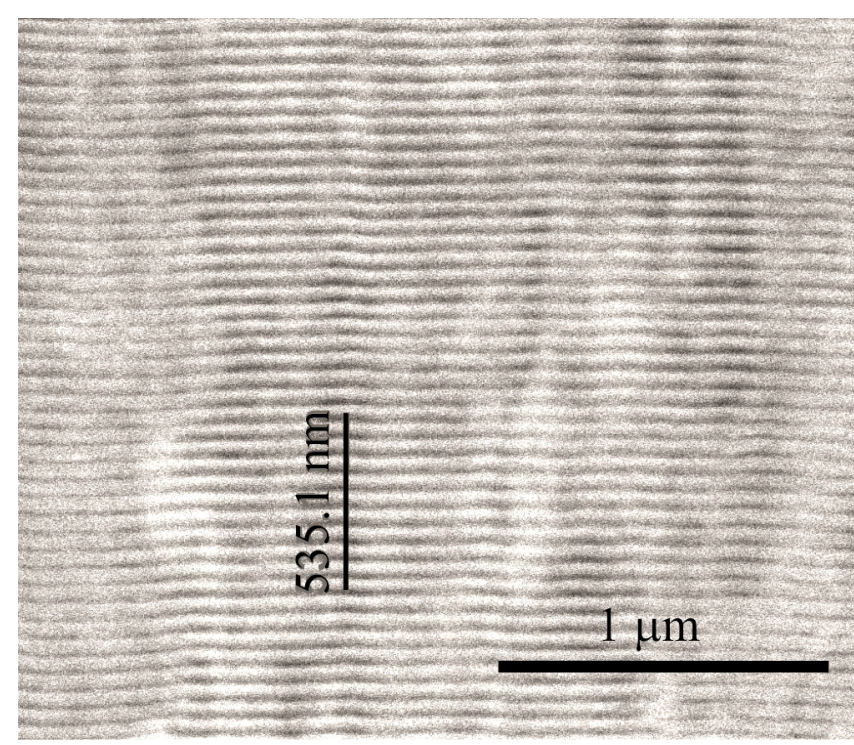

a

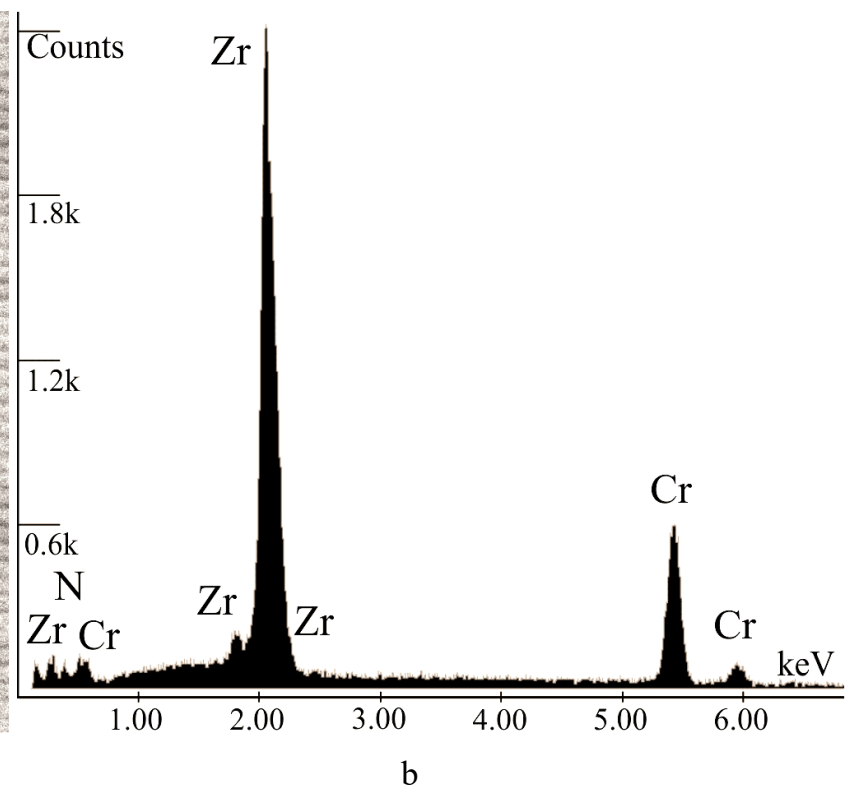

$\mathrm{b}$

Fig. 1. Cross-sectional SEM image (a) and EDS spectrum (b) of multilayer $\mathrm{ZrN} / \mathrm{CrN}$ coating number 4

Shown in Fig. 1b EDS spectrum is composed of $\mathrm{Zr}, \mathrm{Cr}$ and $\mathrm{N}$ peaks, that confirms the purity of elemental composition of the coating number 4 . The chemical compositions of multilayer $\mathrm{ZrN} / \mathrm{CrN}$ coatings are generalized in Table 2 together with the total and bilayer thicknesses extracted from SEM images using ImageJ software.

It is seen from data collected via SEM and EDS that obtained coatings have the nanoscale bilayer thickness within the range from 53 to $70 \mathrm{~nm}$ and near-stoichiometric or stoichiometric composition as an atomic percentage of nitrogen 
changes from 46 to 51. It is obvious, that for experimental coatings there is a tendency to decrease the concentration of metal elements with increasing nitrogen pressure. The lower chromium concentration in comparison with the zirconium concentration is due to the fact that chromium has a lower atomic mass $(\mathrm{Cr}=51.99 \mathrm{~g} / \mathrm{mol} \mathrm{vs}$. $\mathrm{Zr}=91.22 \mathrm{~g} / \mathrm{mol})$, that is, it is a lighter element. The fact is that in the process of coating deposition, when the plasma energy and, accordingly, the intensity of deposition increases, with an increase in $P_{N}$, lighter atoms may escape from the surface coating layer, which leads to an increase of another element concentration in the coating.

Table 2. Characteristics of multilayer $\mathrm{ZrN} / \mathrm{CrN}$ coatings: average coating thickness, bilayer period and chemical composition.

\begin{tabular}{|c|c|c|c|c|c|}
\hline \multirow{2}{*}{ Sample number } & \multirow{2}{*}{$\begin{array}{c}\text { Coating } \\
\text { thickness } D, \mu \mathrm{m}\end{array}$} & \multirow{2}{*}{$\begin{array}{c}\text { Bilayer period } \lambda, \\
\mathrm{nm}\end{array}$} & \multicolumn{3}{|c|}{ Chemical composition, at.\% } \\
\cline { 4 - 6 } & 11.5 & 65 & 46 & $\mathrm{~N}$ & $\mathrm{Cr}$ \\
\hline 1 & 12.4 & 70 & 50 & 27 & 24 \\
\hline 2 & 16.0 & 90 & 51 & 29 & 23 \\
\hline 3 & 9.4 & 53 & 47 & 35 & 18 \\
\hline 4 & & & &
\end{tabular}

\section{Structural characterization}

$\mathrm{X}$-ray diffraction patterns of multilayer $\mathrm{ZrN} / \mathrm{CrN}$ composites are shown in Fig. 2. As seen in this figure, at all values range of nitrogen pressure there is a clear (200) preferred orientation for $\mathrm{ZrN}$ layers and (111) preferred orientation for CrN layers (non-isostructured multilayers). For the coatings deposited at low bias potential, the texture of the $\mathrm{ZrN}$ layer with orientation (111) appears at the patterns. This behavior suggests the prerequisites for the cube-oncube epitaxial growth. Some small contributions of $\mathrm{ZrN}(220)$ reflection are identified for samples number 1 and 2, but it disappears for larger values of $U_{S}$.

The texture coefficient $T_{C}$ of (200) plane with respect of (111) plane for $\mathrm{ZrN}$ phase and $T_{C}$ of (111) plane of $\mathrm{Cr}_{2} \mathrm{~N}$ phase with respect of (111) plane of $\mathrm{CrN}$ phase (samples 1 and 2) was calculated by the equation [11]:

$$
T_{C}(h k l)=\frac{I(h k l) / I_{0}(h k l)}{(1 / N)\left[\sum_{N} I(h k l) / I_{0}(h k l)\right]},
$$

where $I(\mathrm{hkl})$ is the integrated intensity of the diffraction plane calculated using an approximation of the pseudo-Voight function, $I_{0}(\mathrm{hkl})$ is the relative intensity of the corresponding plane given in ICDD, and $N$ is the number of reflections.

The evolution of the crystallography texture coefficient in the function of the working gas pressure is clearly observed in Table 3. For the low values of $P_{N}$, the texture coefficient values are 2.35 and 1.12 for the $\mathrm{ZrN}$ and the $\mathrm{Cr}_{2} \mathrm{~N}$, respectively. As the nitrogen pressure increases, the coefficient for both phases lightly and respectively diminishes going to values between 1.51 for the $\mathrm{ZrN}$ and 1.07 for the $\mathrm{Cr}_{2} \mathrm{~N}$.

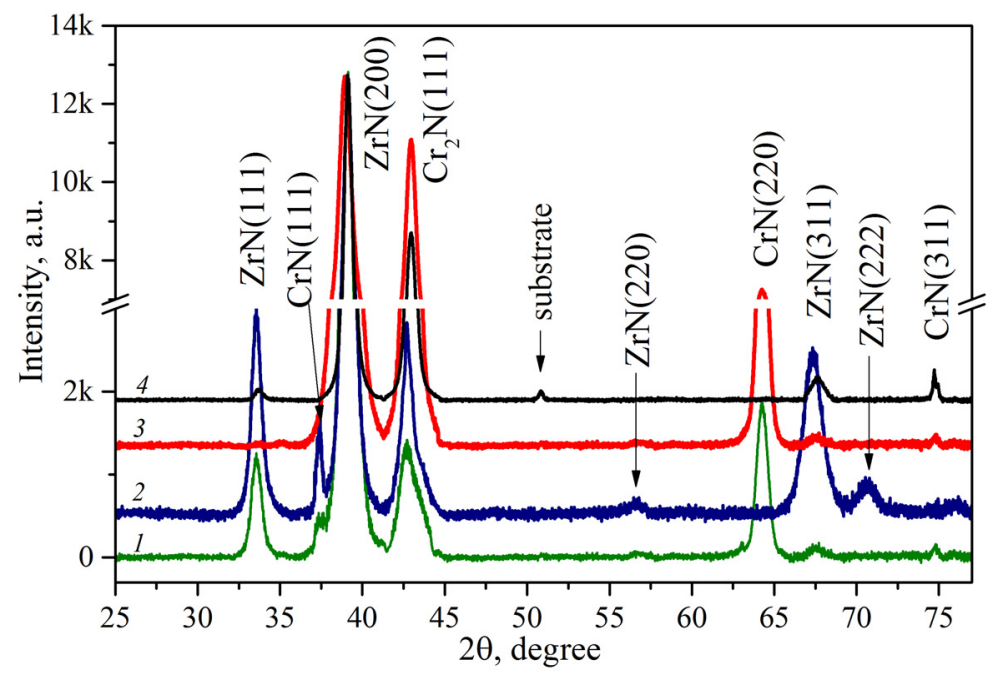

Fig. 2. X-ray diffraction data obtained from multilayer $\mathrm{ZrN} / \mathrm{CrN}$ coatings

The X-ray method for determining internal stresses is based on the fact that the elastic deformation of the crystal lattice is expressed by the changes in inter-planar distance and diffraction angle in the X-ray patterns. It is necessary to point out one feature of the X-ray method for measuring residual stresses. The X-ray diffraction line is formed as a result of the total reflection from those crystallographic planes for which the Wulff-Bragg condition is satisfied. Thus, all calculations carried out on the basis of measuring the angular positions of X-ray lines provide information on the 
stress state of only certain oriented grains of a polycrystalline sample. In this study, the lattice strains $\varepsilon$ of $\mathrm{ZrN}$ and $\mathrm{CrN}$ were calculated according to the following equation based on (200) $\mathrm{ZrN}$ and (111) $\mathrm{Cr}_{2} \mathrm{~N}$ planes [12]:

$$
\varepsilon=\frac{d-d_{0}}{d_{0}}
$$

where $d_{0}$ is the inter-planar distance of distinct $(h \mathrm{kl}$ ) planes of the residual stress-free lattice and $d$ is the inter-planar distance of the same planes influenced by residual stress. It is obvious from the Table 3 that the strains of the $\mathrm{ZrN}$ is greater than those of the $\mathrm{CrN}$, indicating a larger formation of dislocations and defects in $\mathrm{ZrN}$ lattice. These dislocations cause the subdivision of the original crystallites of larger size into domains (small crystallites), producing tensile and compressive strains within diminished crystallites [13].

Table 3.

Values of strain-size parameters calculated from X-ray patterns of $\mathrm{ZrN} / \mathrm{CrN}$ coatings

\begin{tabular}{|c|c|c|c|c|c|c|c|c|}
\hline $\begin{array}{c}\text { Sample } \\
\text { number }\end{array}$ & $\begin{array}{c}\text { Investigated } \\
\text { phase and } \\
\text { plane }\end{array}$ & $\begin{array}{c}\text { Experimental } \\
\text { diffraction } \\
\text { angle } 2 \theta, \text { deg }\end{array}$ & $\begin{array}{c}\text { Standard } \\
\text { diffraction } \\
\text { angle } 2 \theta_{0}, \text { deg }\end{array}$ & $\begin{array}{c}\text { Experimental } \\
\text { inter-planar } \\
\text { distance } d, \\
\text { nm }\end{array}$ & $\begin{array}{c}\text { Standard } \\
\text { inter-planar } \\
\text { distance } d_{0}, \\
\text { nm }\end{array}$ & $\begin{array}{c}\text { Crystallite } \\
\text { size } L, \mathrm{~nm}\end{array}$ & $\begin{array}{c}\text { Texture } \\
\text { coefficient } \\
T c\end{array}$ & $\begin{array}{c}\text { Lattice } \\
\text { strain } \\
\varepsilon, \%\end{array}$ \\
\hline \multirow{2}{*}{1} & $\mathrm{ZrN}(200)$ & 39.10 & 39.13 & 0.2305 & 0.2309 & 11 & 2.35 & -0.17 \\
\cline { 2 - 10 } & $\mathrm{Cr}_{2} \mathrm{~N}(111)$ & 42.77 & 42.72 & 0.2111 & 0.2114 & 7 & 1.12 & -0.14 \\
\hline \multirow{2}{*}{2} & $\mathrm{ZrN}(200)$ & 39.12 & 39.13 & 0.2302 & 0.2309 & 12 & 1.51 & -0.30 \\
\cline { 2 - 9 } & $\mathrm{Cr}_{2} \mathrm{~N}(111)$ & 42.77 & 42.72 & 0.2112 & 0.2114 & 10 & 1.07 & -0.09 \\
\hline \multirow{2}{*}{3} & $\mathrm{ZrN}(200)$ & 39.10 & 39.13 & 0.2305 & 0.2309 & 14 & 2.05 & -0.17 \\
\cline { 2 - 10 } & $\mathrm{Cr}_{2} \mathrm{~N}(111)$ & 42.79 & 42.72 & 0.2112 & 0.2114 & 12 & - & -0.09 \\
\hline \multirow{2}{*}{4} & $\mathrm{ZrN}(200)$ & 39.12 & 39.13 & 0.2306 & 0.2309 & 13 & 2.67 & -0.13 \\
\cline { 2 - 9 } & $\mathrm{Cr}_{2} \mathrm{~N}(111)$ & 42.78 & 42.72 & 0.2110 & 0.2114 & 11 & - & -0.18 \\
\hline
\end{tabular}

Peaks obtained from $\mathrm{ZrN}$ demonstrate the shift toward lower angles ( $2 \theta$ ranged from 39.10 to $39.12^{\circ}$ ), that signifies the existence of compressive stresses in $\mathrm{ZrN}$ layers. A significant movement of the $\mathrm{Cr}_{2} \mathrm{~N}$ peaks towards higher angles $\left(2 \theta=42.77\right.$ and $\left.42.79^{\circ}\right)$ in relation to standard values $\left(2 \theta=42.72^{\circ}\right)$ shows the presence of tensile stresses in $\mathrm{CrN}$ layers.

\section{Mechanical properties}

Hardness values of the multilayer $\mathrm{ZrN} / \mathrm{CrN}$ coatings measured using the Vickers tip, which is a four-sided pyramid, are presented in Fig. 3. All samples acquire the hardness that overperforms the corresponding value of individual coatings, i.e., $\mathrm{CrN}$ and $\mathrm{ZrN}$ monolayers. It is observed a hardness-increasing trend as the nitrogen pressure in the vacuum chamber decreases. The highest hardness of $6600 \mathrm{HV} 0.01$ is obtained for sample number 2 with stoichiometric composition of 50 at. $\% \mathrm{~N}$ and bilayer period of $70 \mathrm{~nm}$, that is on $51 \%$ and $47 \%$ greater than referent value from $\mathrm{ZrN}$ and $\mathrm{CrN}$ coatings, respectively.

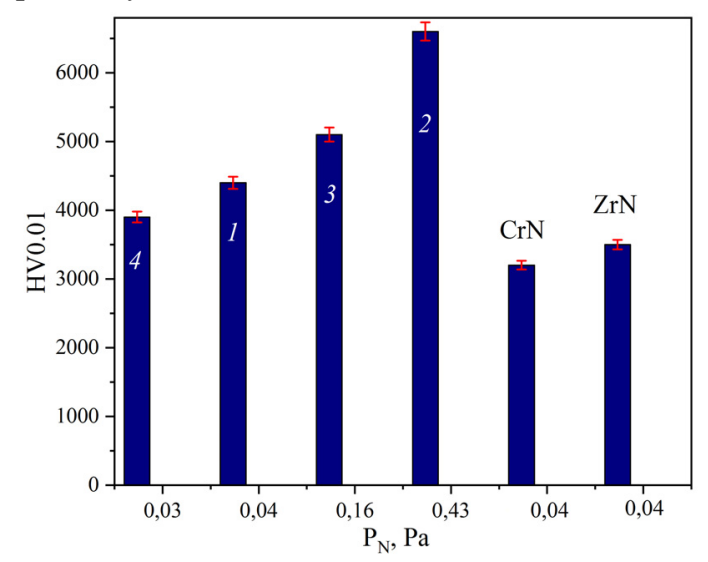

Fig. 3. Variation of microhardness with nitrogen pressure values for the multilayer $\mathrm{ZrN} / \mathrm{CrN}$ coatings and binary $\mathrm{ZrN}$ and $\mathrm{CrN}$ coatings.

In general, the increase of the mechanical properties of multilayer coating lies in application of the multilayer concept that possess the following conditions: (i) the presence of many interfaces that blocks the dislocation movement across the interface between $\mathrm{ZrN}$ and $\mathrm{CrN}$ layers: (ii) coherency strains cause periodical strain-stress fields due to the lattice-mismatch in the multilayer coating; (iii) the formation of the discrete layers in the multilayer system, which observed in the SEM results; (iv) the formation of partial correlation within (111) crystallography direction between $\mathrm{ZrN}$ and $\mathrm{CrN}$ layers. 


\section{CONCLUSIONS}

In summary, the morphological and structural-phase characteristics, as well as mechanical properties of multilayer $\mathrm{ZrN} / \mathrm{CrN}$ coatings grown on stainless steel substrates by the cathodic arc deposition were studied.

It was shown that the surface of the multilayer composited contained droplet particles, which concentration depended on negative bias potential applied to the steel substrate. The total thickness of the obtained films ranged from 9.4 to $16.0 \mu \mathrm{m}$, while the bilayer period varied from 53 to $90 \mathrm{~nm}$. The elemental composition of cathodic arc coatings depended on working gas pressure, hence, at high values of $P_{N}$ formed coatings had the stoichiometric composition (50-51 at.\%).

Additionally, different deposition conditions, i.e. nitrogen pressure and substrate bias, promoted the preferred formation of two phases $\mathrm{ZrN}(200)$ and $\mathrm{Cr}_{2} \mathrm{~N}(111)$, but at $U_{S}=-70 \mathrm{~V}$ the intensive peak of $\mathrm{ZrN}(111)$ and reflex of $\mathrm{CrN}(111)$ were found on diffraction patterns.

The enhancement in microhardness of multilayer $\mathrm{ZrN} / \mathrm{CrN}$ coatings was observed for all experimental samples. The maximum value $6600 \mathrm{HV} 0.01$ was found for the sample number 2 of stoichiometric composition (51 at. $\% \mathrm{~N}$ ) obtained at $P_{N}=0.43 \mathrm{~Pa}, U_{S}=-70 \mathrm{~V}$. Presented findings prove that multilayer $\mathrm{ZrN} / \mathrm{CrN}$ coatings are appropriate for use as protective materials due to high hardness. However, the tribological, thermal and oxidation experiments of multilayer $\mathrm{ZrN} / \mathrm{CrN}$ systems need to be done in order to find out their potential and extend the range of possible applications.

\section{ACKNOWLEDGEMENTS}

Presented work was financially supported by budget programs: "Multilayer and multicomponent coatings with adaptive behavior in wear and friction conditions" (No 0118U003579) and "Physical properties of the two-dimensional nanomaterials and metallic nanoparticles" (No. 0117U003923).

\section{ORCID IDs}

Olga Maksakova $@$ https://orcid.org/0000-0002-0646-6704, Alexander Pogrebnjak $@$ https://orcid.org/0000-0002-9218-6492, Vyacheslav Stolbovoy@https://orcid.org/0000-0001-7734-0642, Sónia Simoẽs Đhttps://orcid.org/0000-0003-4670-4516

\section{REFERENCES}

[1]. D.M. Sanders, D.B. Boercker, and S. Falabella, IEEE Trans. Plasma Sci. 18, 883 (1990), doi: 10.1109/27.61499.

[2]. O. Knotek, W.D. Münz, and T. Leyendecker, J. Vac. Sci. Technol. A Vacuum, Surfaces, Film. 5, 2173 (1987), doi: $10.1116 / 1.574948$.

[3]. H. Willmann, P.H. Mayrhofer, P.O.Å. Persson, A.E. Reiter, L. Hultman, and C. Mitterer, Scr. Mater. 54, 1847 (2006), doi: 10.1016/j.scriptamat.2006.02.023.

[4]. H.C. Barshilia and K.S. Rajam, J. Mater. Res. 19, 3196 (2004), doi 10.1557/JMR.2004.0444.

[5]. A.P. Ehiasarian, P.E. Hovsepian, L. Hultman and U. Helmersson, Thin Solid Films. 457, 270 (2004), doi: 10.1016/j.tsf.2003.11.113.

[6]. X.M. Xu, J. Wang, J. An, Y. Zhao and Q.Y. Zhang, Surf. Coatings Technol. 201, 5582 (2007), doi: 10.1016/j.surfcoat.2006.07.132.

[7]. A.D. Pogrebnjak, Ya.O. Kravchenko, O.V. Bondar, B. Zhollybekov and A.I. Kupchishin, Prot. Met. Phys. Chem. Surfaces. 54, 240 (2018), doi: 10.1134/S2070.

[8]. O.V. Maksakova, S. Simoẽs, A.D. Pogrebnjak, O.V. Bondar, Ya.O. Kravchenko, T.N. Koltunowicz and Zh.K. Shaimardanov, J. Alloys Compd. 776, 679 (2019), doi: 10.1016/j.jallcom.2018.10.342.

[9]. D.M. Mattox, in: Deposition Technologies for Films and Coatings, edited by R.F. Bunshah (Noyes, Park Ridge, NJ, 1982), pp. 63-82.

[10]. M. Pohler, R. Franz, J. Ramm, P. Polcik and C. Mitterer, Surf. Coatings Technol. 206, 1454 (2011), doiL 10.1016/j.surfcoat.2011.09.028.

[11]. C. Agashe, B.R. Marathe, M.G. Takwale and V.G. Bhide, Thin Solid Films. 164, 261 (1988), doi: 10.1016/00406090(88)90146-0.

[12]. F.H. Chung and D.K. Smith, Industrial Applications of X-Ray Diffraction, 1st ed. (CRC Press, New York, 1999$)$ ), p. 1024.

[13]. H.P. Klug and L.E. Alexander, X-Ray Diffraction Procedures for Polycrystalline and Amorphous Materials, 2nd ed. (John Wiley \& Sons, New York, 1974), p. 960.

\section{ДОСЛІДЖЕННЯ ПЕРСПЕКТИВНИХ НАНОРОЗМІРНИХ ZRN/CRN БАГАТОШАРОВИХ ПОКРИТТІВ}

О.В. Максакова ${ }^{1}$, О.Д. Погребняк ${ }^{1,2}$, В.М. Береснсв ${ }^{3}$, В.О. Столбовий ${ }^{4}$, S. Simoе̃s $^{5}$, Д. Срболатули

${ }^{I}$ Сумський державний університет, вул. Римського-Корсакова, 2, 40007 Суми, Украӥна

${ }^{2}$ Східно-Казахстанський державний технічний університет ім. Д. Серікбаева вул. Протозанова, 69, 070004 Усть-Каменогірськ, Республіка Казахстан

${ }^{3}$ Харківський національний університет імені В.Н. Каразіна, майд. Свободи 4, 61022 Харків, Украӥна

${ }^{4}$ Начіональний науковий центр Харківський фізико-технічний інститут, вул. Академічна 1, 61108 Харків, Украйна

${ }^{5}$ University of Porto, R. Dr. Roberto Frias, 4200-465 Porto, Portugal

${ }^{6}$ Східно-Казахстанський державний університет імені Сарсена Аманжолова

вул. 30-ї Гвардійської дивізї̈, 34, 070020 Усть-Каменогірськ, Республіка Казахстан

Науковий інтерес до дослідження нітридних композитів в якості захисних матеріалів в інструментальній та обробній промисловостях інтенсивно зростає. Хороша стійкість до окислення одношарових плівок $\mathrm{CrN}$ i висока температура плавлення, хороша хімічна і термічна стійкість $\mathrm{ZrN} є$ рушійними факторами для створення багатошарових композитів, в яких використовуються нітриди цих перехідних металів. Передбачувані переваги багатошарових покриттів в якості 
конструкційних матеріалів - це висока термостійкість, висока щільність їх структури і покращена твердість у порівнянні 3 системами нітрид-метал. Багатошарові покриття $\mathrm{ZrN} / \mathrm{CrN}$ осаджувалися на сталеві підкладки AISI 321 за допомогою вакуумно-дугового пристрою, оснащеного двома металевими мішенями $\mathrm{Cr}$ і Zr високої чистоти. Структурні, хімічні та морфологічні характеристики, а також механічні властивості багатошарових композитів були проаналізовані за допомогою рентгенівської дифракції, растрової електронної мікроскопії, енергодисперсійної рентгенівської спектроскопії і твердоміра, оснащеного пірамідкою Віккерса. РЕМ-аналіз виявив збільшення шорсткості і концентрації крапель на поверхні покриттів, коли негативний потенціал зсуву знижувався до значення в -70 В. Результати даних, отриманих від рентгеноструктурного аналізу, показали, що найбільш інтенсивними $є$ площини (200) і (111) для $\mathrm{ZrN}$ i Cr $2 \mathrm{~N}$ фази, відповідно. Положення піків $\mathrm{ZrN}$ були зміщені в бік менших кутів дифракції в порівнянні з об'ємними значеннями і вказували на зменшення міжплощинної відстані і формування стискаючих напружень. Розраховані значення напруження решітки в $\mathrm{ZrN}$ вище, ніж у CrN, що свідчить про більшу наявності дислокацій і дефектів в решітці ZrN. Усереднені розміри кристалітів в шарах $\mathrm{ZrN}$ і CrN становили 11-14 і 7-12 нм відповідно. Було встановлено, що максимальне значення мікротвердості по Віккерсу становить $6600 \mathrm{HV} 0.01$, що в 2,1 і 1,8 рази більше, ніж відповідні значення бінарних покриттів $\mathrm{CrN}$ i ZrN.

КЛЮЧОВІ СЛОВА: нітриди, вакуумно-дугове осадження, мікроструктура, елементний склад, структурно-фазовий стан.

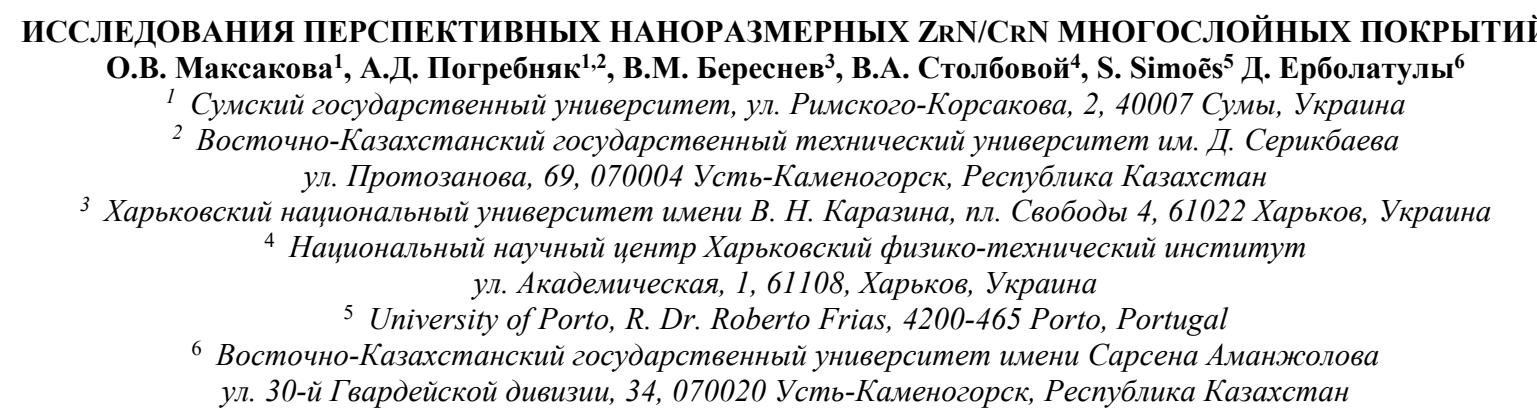

Научный интерес к исследованию нитридных композитов как защитных материалов в инструментальной и обрабатывающей промышленности интенсивно возрастает. Хорошая стойкость к окислению однослойных пленок CrN и высокая температура плавления, хорошая химическая и термическая стойкость $\mathrm{ZrN}$ являются движущими факторами для создания многослойных композитов, в которых используются нитриды этих переходных металлов. Предполагаемые преимущества многослойных покрытий в качестве конструкционных материалов - это высокая термостойкость, высокая плотность их структуры и чрезвычайная твердость по сравнению с системами нитрид-металл. Многослойные покрытия $\mathrm{ZrN} / \mathrm{CrN}$ наносились на стальные подложки AISI 321 с использованием вакуумно-дугового устройства, оснащенного двумя металлическими мишенями $\mathrm{Cr}$ и $\mathrm{Zr}$ высокой чистоты. Структурные, химические и морфологические характеристики, а также механические свойства многослойных композитов были проанализированы с помощью рентгеновской дифракции, растровой электронной микроскопии, энергодисперсионной рентгеновской спектроскопии и твердомера, оснащённого пирамидкой Виккерса. РЕМ-анализ выявил увеличение шероховатости и концентрации капель на поверхности покрытий, когда отрицательный потенциал смещения снижался до значения в -70 В. Результаты данных, полученных от рентгеноструктурного анализа, показали, что наиболее интенсивными являются плоскости (200) и (111) для $\mathrm{ZrN}$ и $\mathrm{Cr} 2 \mathrm{~N}$ фазы, соответственно. Положения пиков $\mathrm{ZrN}$ были смещены в сторону меньших углов дифракции по сравнению с объемными значениями и указывали на уменьшение межплоскостного расстояния и присутствие сжимающих напряжений. Рассчитанные значения напряжений решетки в $\mathrm{ZrN}$ выше, чем у CrN, что свидетельствует о большем наличии дислокаций и дефектов в решетке $\mathrm{ZrN}$. Усредненные размеры кристаллитов в слоях $\mathrm{ZrN}$ и $\mathrm{CrN}$ составляли 11-14 и 7-12 нм соответственно. Было установлено, что максимальное значение микротвердости по Виккерсу составляет 6600HV0.01, что в 2,1 и 1,8 раза больше, чем соответствующие значения бинарных покрытий $\mathrm{CrN}$ и $\mathrm{ZrN}$.

КЛЮЧЕВЫЕ СЛОВА: нитриды, вакуумно-дуговое осаждение, микроструктура, элементный состав, структурно-фазовое состояние. 